\title{
Implementasi Scientific Approach Terhadap Pendidikan Karakter Peserta Didik di SD Negeri Dukuh Nanggulan
}

\author{
Siwi Utaminingtyas \\ IKIP PGRI Wates \\ siwiutaminingtyas@ipw.ac.id
}

\section{Article History}

accepted 24/09/2019

\begin{abstract}
Character education continues to be pursued, seeing the situation of the community even the situation of the education world in Indonesia becomes the main motivation for the mainstreaming of the implementation of character education. Character education in Indonesia is felt very necessary to develop when looking at the moral crisis experienced by the people of Indonesia. This is what the Government is trying to do, changing the view that education is not only limited to obtaining grades or ranks, but needs to strengthen a character in students, especially in elementary school. One of the efforts undertaken by the Government is curriculum renewal, namely the 2013 Curriculum. Through the implementation of the 2013 curriculum which is character-based with a Scientific Approach (scientific approach) designed in all components of learning is expected to be able to independently improve and use the knowledge gained from learning in class, examine and internalize and personalize character values in daily life.
\end{abstract}

Keyword: scientific approach, character education, elementary school

\begin{abstract}
Abstrak
Pendidikan karakter terus diupayakan, melihat situasi masyarakat bahkan situasi dunia pendidikan di Indonesia menjadi motivasi pokok pengutamaan (mainstreamming) implementasi pendidikan karakter. Pendidikan karakter di Indonesia dirasakan sangat perlu pengembangannya bila melihat krisis moral yang dialami masyarakat Indonesia. Inilah yang diupayakan oleh Pemerintah, mengubah pandangan bahwa pendidikan bukan hanya sebatas memperoleh nilai ataupun peringkat, namun perlu adanya penguatan sebuah karakter pada peserta didik terutama di bangku Sekolah Dasar. Salah satu upaya yang dilakukan oleh Pemerintah adalah pembaharuan kurikulum, yaitu Kurikulum 2013. Melalui implementasi kurikulum 2013 yang berbasis karakter dengan Scientific Approach (pendekatan ilmiah) yang dirancang dalam semua komponen pembelajaran diharapkan mampu secara mandiri meningkatkan dan menggunakan pengetahuannya yang didapat dari pembelajaran di kelas, mengkaji dan menginternalisasi serta mempersonalisasi nilai-nilai karakter dalam kehidupan sehari-hari.
\end{abstract}

Kata kunci: scientific approach, pendidikan karakter, sekolah dasar

Social, Humanities, and Education Studies (SHEs): Conference Series https://jurnal.uns.ac.id/shes

p-ISSN 2620-9284

e-ISSN 2620-9292 


\section{PENDAHULUAN}

Pendidikan saat ini dinilai sudah mengalami pergeseran makna yaitu menuju pada konsep pengajaran yang lebih cenderung mengunggulkan angka' atau score. Masnur Muslich (2011: 17) mengatakan pendidikan saat ini terlalu banyak memberikan porsi pada aspek pengetahuan, dan kurang bisa mengembangkan nilai, sikap, dan karakter. Dalam proses pembelajarannya pun nilai-nilai diajarkan sebagai sesuatu yang terpisah dan sebatas hanya untuk dipahami tidak diwujudkan dalam kehidupan sehari-hari. Selain itu, materi-materi pembelajaran yang memuat nilai dan karakter banyak dibebankan pada mata pelajaran Agama dan Pendidikan Kewarganegaraan (PKn) saja.

Zubaedi (2011: 1) menyatakan bahwa Indonesia saat ini sedang menghadapi tantangan besar, yaitu mengatasi krisis moral yang terjadi secara nyata dan mengkhawatirkan dalam masyarakat indonesia. Krisis itu antara lain berupa meningkatnya pergaulan seks bebas, kekerasan anak-anak dan remaja, tawuran, perdagangan manusia, penyalahgunaan obat-obatan, pornografi, pemerkosaan, dan kebiasaan menyontek. Berita dari media masa baik dalam surat kabar, artikel dalam internet, dan media elektronik mengungkapkan semakin banyak masalah-masalah sosial yang terjadi di Indonesia.

Oleh karena itu banyak cara yang dilakukan oleh Pemerintah untuk memperkenalkan dan menerapkan pendidikan karakter sedini mungkin, salah satunya adalah pembaharuan kurikulum 2013 yang lebih menekankan pada pendidikan karakter terutama pada tingkat dasar yang menjadi pondasi bagi tingkat selanjutnya. Melalui implementasi kurikulum 2013 yang berbasis kompetensi sekaligus berbasis karakter dengan Scientific Approach (pendekatan ilmiah) diharapkan peserta didik mampu secara mandiri meningkatkan dan menggunakan pengetahuannya yang didapat dari pembelajaran di kelas, mengkaji dan menginternalisasi serta mempersonalisasi nilai-nilai karakter dalam kehidupan sehari-hari.

Implementasi kurikulum 2013 sangat menonjolkan pendekatan saintifik dengan pembelajaran yang berpusat pada peserta didik. Scientific approach merupakan sebuah pendekatan yang digunakan dalam proses pembelajaran. Pendekatan saintifik dapat dikatakan sebagai proses pembelajaran yang memandu siswa untuk memecahkan suatu permasalahan melalui kegiatan perencanaan yang matang, mengumpulkan data yang cermat, dan analisis data yang teliti untuk menghasilkan sebuah kesimpulan. Kepmendiknas mengidentifikasi terdapat 18 nilai untuk pendidikan budaya dan karakter bangsa seperti nilai religius, jujur, kreatif, kerja keras, mandiri, demokratis, cinta tanah air, gemar membaca, cinta damai, peduli, dan tanggung jawab. Nilai-nilai tersebut dapat dirancang melalui penyusunan perangkat pembelajaran dan dapat diaplikasikan dengan pendekatan ilmiah (Scientific Approach) yang meliputi Mengamati, Menanya, Mencoba, Mengkomunikasikan, dan Mengkomunikasikan. Dari 5 M Scientific Approach ini, siswa dapat mengembangkan nilai-nilai karakter dalam pembelajaran.

\section{METODE}

Penelitian ini merupakan penelitian deskriptif yang dilakukan untuk memperoleh gambaran mengenai pengaruh program parenting terhadap pengetahuan dan sikap orang tua dalam pemenuhan kebutuhan dasar anak di Desa Karangtanjung. Penyampaian materi program parenting dilakukan dengan metode ceramah dan tanya jawab. Instrumen penelitian ini terdiri dari lembar pretest, posttest, angket dan wawancara yang diadopsi dari Kebijakan Teknis Pelibatan Keluarga dan Masyarakat di Satuan Pendidikan yang disampaikan oleh Kementerian Pendidikan dan Kebudayaan. Subjek penelitian adalah 10 orang ibu yang memiliki anak usia sekolah dasar dengan latar belakang profesi yang berbeda. Teknik analisis data menggunakan reduksi data, display data, dan penarikan kesimpulan. 
Untuk mencari besar presentase keberhasilan menggunakan persamaan berikut.

$$
\text { Presentase Keberhasilan }(p)=\frac{\text { Skoryang didapatkan }}{\text { Skor Maksimal }} \times 100 \%
$$

\section{HASIL DAN PEMBAHASAN}

Program parenting berbasis keluarga merupakan program dukungan yang ditujukan kepada para orang tua atau anggota keluarga lain agar semakin memiliki pengetahuan dan kemampuan dalam mengasuh, merawat, melindungi dan mendidik anaknya di rumah sehingga anak dapat tumbuh dan berkembang secara optimal sesuai usia dan tahap perkembangannya. Manfaat kegiatatan parenting, yaitu dapat membangun komunikasi yang baik antara lembaga dengan orang tua. Sehingga pola pengasuhan yang dijalankan di lembaga dengan yang diterapkan orang tua dirumah selaras, melalui kegiatan parenting juga orangtua dapat mengetahui capaian perkembangan anak, hak-hak dasar apa saja yang harus dipenuhi orang tua dalam kelangsungan hidup anak, dan memberikan pengetahuan kepada orang tua (Ganevi, 2013).

\section{Pelaksanaan Program Parenting di Lingkungan Masyarakat}

Metode yang digunakan dalam pelaksanaan program parenting di Desa Karangtanjung yaitu metode ceramah dan tanya jawab. Hal ini dilakukan agar antara pembicara dan peserta parenting dapat berinteraksi dengan baik. Media yang digunakan yaitu modul yang berjudul modul program parenting yang berisi pemahaman pola asuh, gizi seimbang, dan psikologi anak. Semua materi tersebut sesuai dengan Kebijakan Teknis Pelibatan Keluarga dan Masyarakat di Satuan Pendidikan yang disampaikan oleh Kementerian Pendidikan dan Kebudayaan. Pelaksanaan program parenting bertempat di salah satu rumah warga di Desa Karangtanjung dengan konsep lesehan. Program ini ditujukan kepada orang tua yang mempunyai anak sekolah dasar sebagai pesertanya yang dilaksanakan pada hari Jumat tanggal 27 September 2019 pukul 14.30-16.30 WIB. Proses pelaksanaan program parenting meliputi pembukaan, pretest, penyampaian materi, posttest, pengisian angket dan wawancara. Jumlah responden sebanyak 10 orang yang memiliki latar belakang profesi dan pengetahuan yang berbeda. Sebanyak $20 \%$ berprofesi sebagai pedagang dan selebihnya sebagai ibu rumah tangga. berdasarkan pengamatan hanya $10 \%$ dari jumlah responden yang sudah pernah mengikuti kegiatan parenting.

\section{Meningkatkan Pengetahuan Orang tua akan Pola Asuh yang Benar Sesuai Tahap} Perkembangan Anak Sebesar yaitu 12\% yang Diperoleh dari Hasil Posttest

Menurut Notoatmodjo dalam Setijaningsih dan Mariningsih (2014) pengetahuan adalah merupakan hasil "tahu" dan ini terjadi setelah orang mengadakan penginderaan terhadap suatu objek tertentu. Penginderaan terhadap obyek terjadi melalui panca indra manusia yakni penglihatan, pendengaran, penciuman, rasa dan raba dengan sendiri. Partisipasi orang tua merupakan tingkat kerjasama yang lebih luas dan tinggi tingkatannya. Orang tua dan sekolah duduk Bersama untuk membicarakan berbagai program dan kegiatan anak. Orang tua datang ke sekolah untuk membantu guru melaksanakan tugas-tugas rutin, seperti menyiapkan makanan, menyiapkan alat/media yang dibutuhkan untuk pembelajaran, dan ikut menjadi keamanan. Berdasakan pretest yang telah dilakukan menghasilkan rata-rata presentase keberhasilan sebesar $65 \%$ dan pada hasil posttest $77 \%$, sehingga terjadi peningkatan sebesar $12 \%$. Hal ini menunjukkan bahwa adanya sosialisasi program parenting dengan pemberian modul dan penjelasan materi dapat meningkatkan pengetahuan orang tua mengenai pola asuh, gizi seimbang dan psikologi anak. Semua materi yang disampaikan bisa terserap 
dan memberikan dampak baik terhadap orang tua kepada anak. Hal ini dapat diketahui berdasarkan hasil wawancara yang telah dilakukan setelah pengerjaan posttest.

\section{Meningkatkan Kepedulian Orang tua terhadap Asupan Gizi Seimbang yang Penting Untuk Tumbuh Kembang Anak}

Menurut Permenkes nomor 41 tahun 2014 menyatakan bahwa pola makan merupakan perilaku paling penting yang dapat mempengaruhi keadaan gizi. Hal ini disebabkan karena kuantitas dan kualitas makanan dan minuman yang dikonsumsi akan mempengaruhi asupan gizi sehingga akan mempengaruhi kesehatan individu dan masyarakat. Berdasarkan wawancara yang dilakukan menunjukkan perubahan perilaku yang sebelumnya tidak memperhatikan asupan gizi menjadi lebih memperhatikan dengan pembiasaan sarapan pagi yang terdiri dari pangan karbohidrat, pangan lauk pauk, sayuran atau buah-buahan dan minuman. Dengan asupan tersebut orang tua di Desa Karangtanjung berharap anak mereka bisa tumbuh dan berkembang sesuai dengan usianya. Selain itu, orang tua berharap anak menjadi pintar, matang dalam berpikir dan bertindak. Hal tersebut sesuai dengan Permenkes nomor 41 tahun 2014 yaitu bagi anak sekolah, sarapan yang cukup terbukti dapat meningkatkan konsentrasi belajar dan stamina. Menurut Setijaningsih dan Mariningsih (2014) sikap merupakan suatu kencenderungan untuk bertindak secara suka atau tidak suka terhadap suatu objek. Sikap dapat dibentuk melalui cara mengamati dan menirukan sesuatu yang positif, kemudian melalui penguatan serta menerima informasi verbal. Perubahan sikap dapat diamati dalam proses pembelajaran, tujuan yang ingin dicapai, keteguhan, dan konsistensi terhadap sesuatu. Fenomena sikap yang timbul tidak saja ditentukan oleh keadaan objek yang sedang dihadapi tetapi juga ada kaitannya dengan pengalaman-pengalaman masa lalu, oleh situasi di saat sekarang, dan oleh harapan untuk masa yang akan datang. Menurut Azwar dalam Setijaningsih dan Mariningsih (2014) menyimpulkan bahwa faktor-faktor yang mempengaruhi pembentukan sikap adalah pengalaman pribadi, kebudayaan, orang lain yang dianggap penting, media massa, institusi atau lembaga pendidikan dan lembaga agama, serta faktor emosi dalam diri individu.

\section{Meningkatkan Pemahaman Orang tua Mengenai Pentingnya Keikutsertaan Orang tua dalam Proses Belajar Anak di Rumah}

Hasil wawancara menunjukkan bahwa pola asuh orang tua sebelum dilakukannya kegiatan sosialisasi parenting dominan menggunakan pola asuh otoriter. Mereka terlalu sering memerintah anak untuk rajin belajar, akan tetapi orang tua tidak ikut mendampingi anak dalam kegiatan belajar di rumah. Sehingga ketika anak belajar, orang tua tidak tahu kegiatan belajar seperti apakah yang sedang dilakukan oleh anak tersebut. Orang tua juga tidak tahu pada tahap apakah kemampuan belajar yang dimiliki oleh sang anak. Kendala-kendala yang dimiliki anak pun tidak diketahui oleh orang tua. Sehingga ketika anak menolak untuk belajar, orang tua hanya melampiaskan emosi dalam bentuk amarah kata-kata yang menjadikan anak lebih tidak berminat untuk belajar. Padahal anak dalam tahap perkembangan sekolah dasar tidak suka terlalu banyak kekangan. Mereka lebih senang bermain sambil belajar dan lebih senang bergerak, senang bekerja kelompok dan senang praktek langsung. Oleh karena itu, orang tua sebagai pendidik pertama dan utama bagi anak haruslah paham dengan karakteristik tersebut. Akan tetapi banyak orang tua yang belum memahami karakteristik tersebut. Oleh karena itu, setelah diadakannya sosialisasi mengenai parenting ini dapat menambah pemahaman orang tua akan pentingnya keikutsertaan orang tua dalam proses belajar anak. Sehingga mereka bersedia menemani putraputrinya dalam kegiatan belajar anak dalam lingkungan keluarga.

\section{SIMPULAN}

Setelah diadakannya program parenting yang dlaksanakan di Desa Karangtanjung dapat disimpulkan bahwa terdapat pengaruh program parenting 
terhadap pengetahuan dan sikap orang tua dalam pemenuhan kebutuhan dasar anak. Dengan adanya program parenting dapat (1) Meningkatkan pengetahuan orang tua akan pola asuh yang benar sesuai tahap perkembangan anak sebesar yaitu $12 \%$ yang diperoleh dari hasil posttest (2) Meningkatkan kepedulian orang tua terhadap asupan gizi seimbang yang penting untuk tumbuh kembang anak. (3) Meningkatkan pemahaman orang tua mengenai pentingnya keikutsertaan orang tua dalam proses belajar anak di rumah.

\section{DAFTAR PUSTAKA}

Burhaen, E. (2017). Aktivitas Fisik Olahraga untuk Pertumbuhan dan Perkembangan Siswa SD. Indonesian Journal of Primary Education Vol 1 No 1 Tahun 2017. Diakses dari http://ejournal.upi.edu/index.php/lJPE/article/download/7497/4860 tanggal 23 September 2019.

Dewan Perwakilan Rakyat RI dan Presiden RI. (2003). Undang-Undang Republik Indonesia Nomor 20 Tahun 2003 Tentang Sistem Pendidikan Indonesia. Jakarta: Sekretaris Negara RI.

Ganevi, N. (2013). Pelaksanaan Program Parenting bagi Orang Tua dalam Menumbuhkan Perilaku Keluarga Ramah Anak (Studi Deskriptif di Pendidikan Anak Usia Dini Al-Ikhlas Kota Bandung). Jurnal Pendidikan Luar Sekolah Vol. 9 $\begin{array}{lllll}\text { Nomor } & 2 & \text { Tahun } & 2013 . & \text { Diakses }\end{array}$ http://ejournal.upi.edu/index.php/pls/article/download/5425/3721 tanggal 10 Sepetember 2019.

Jarvis, M. (2009). Teori-teori Psikologi: Pendekatan Modern untuk Memahami Perilaku, Perasaan \& Pikiran Manusia. Bandung: Nusamedia.

Kementrian Kesehatan Republik Indonesia. (2014). Peraturan Menteri Kesehatan Republik Indonesia tentang Pedoman Gizi Seimbang (Permenkes Nomor 41 tahun 2014). Jakarta: Penulis.

Komariah, Y. (2015). Efektivitas Program Pelatihan Parenting Skill terhadap Peningkatan Pemahaman Orang tua tentang Pola Asuh. Journal Bimbingan dan Konseling Islam Volume 5 Nomor 2 Tahun 2015. Diakses dari http://jurnalbki.uinsby.ac.id/index.php/jurnalbki/article/view/41/pdf 8 pada tanggal 10 September 2019.

Ningsih, F. D., dkk. (2018). Pelaksanaan Program Parenting di Lembaga Paud Kecamatan Basa Ampek Balai Tapan. Jurnal Ilmiah Potensia Vol. 3 (1) Tahun $2018 . \quad$ Diakses dari https://ejournal.unib.ac.id/index.php/potensia/article/download/1759/2686 tanggal 18 September 2019.

Setijaningsih, T., dan Martiningsih, W. (2014). Pengaruh Program Parenting terhadap Pengetahuan dan Sikap Orang Tua dalam Pemenuhan Kebutuhan Dasar Anak Usia Dini. Jurnal Ners dan Kebidanan Vol. 1 No. 2 Tahun 2014. Diakses dari https://media.neliti.com/media/publications/232672-the-effect-of-parentingprogram-towards-4233e85c.pdf tanggal 11 September 2019. 